\title{
Assaying the Impact of Firm's Growth and Performance on Earnings Management: An Empirical Observation of Indian Economy
}

\author{
Pranesh Debnath \\ Assistant Registrar [Finance], Finance Branch, Tripura University [A Central University], Suryamaninagar -
}

\begin{abstract}
Considering the connotation of true and fair financial disclosure practices and corporate governance mechanism in the quickly improving economic scenario, this study attempted to analyses the nature and extent of earnings management practices and also to assess the impact of firm's growth and performance on earnings management through discretionary accruals estimation in India. The study uses cross-sectional modified Jones model to estimate discretionary accruals, a proxy for earnings management. A sample of 756 firm-year observations from non-financial corporate sector (banking and other financial sector was not considered for distinct governance and reporting practices) for nine years from 2007 to 2015, was considered based on some accounting and market measurement criteria from Capitalineplus Corporate Database. The study analyzed the panel data using a fixed effect model to estimate the influence of firm's growth and performance over the discretionary accruals. The findings of the study affirmed that there is an existence of earnings management practices across the Indian nonfinancial firms under study, which followed a mixed trend. Regression analysis of the study witnessed that growth of the firm is positively associated with discretionary accruals while performance is negatively correlated. Nonetheless, among the other control variables viz; firm's size and age were also found statistically significant influencing variables.
\end{abstract}

Keywords: Earnings Management, Discretionary Accruals, Modified Jones Model, Nonfinancial Sectors, Firmyear Observation, Panel Data.

\section{INTRODUCTION}

Earnings management has become a topic of increased importance on observation of accounting scandals ${ }^{1}$ in different developed and emergent economy. According to agency theory of (Jensen \& Meckling, 1976), departure of agent (management) from principal (owners) creates a clash between interests of management and owners. Managers always endeavor to exploit their own interest even at the cost of owners and other stake holders which insisted for exercise of monitoring measurement over the managerial decision making (Fama \& Jensen, 1983). This situation gives birth to the earnings management as we know that preparation, presentation and disclosure of financial statements is done under close monitoring of management, wherein managers exercise their discretionary powers ${ }^{2}$ while reporting the earnings ${ }^{3}$ which would benefits their own interest. Earnings management is a financial reporting phenomenon (Beneish, 2001), which occurs when managers use their personal judgment in financial reporting and in assembling transactions to alter financial reports either to misinform some investors about the underlying economic performance of the company or to influence contractual outcomes that depend on reported accounting outcomes (Healy \& Wahlen, 1999). (Schipper, 1989),

1 The big corporate scams in the United States, such as Enron, WorldCom and Xerox, as well as failures of Parmalat in Italy, AIH in Australia, Flowtex in Germany and Royal Ahold in the Netherlands and finally Satyam in India were noticed which declined the public confidence about published financial statements.

2 Discretionary power of managers in preparation of financial statements comes into operation because accounting standards like Generally Accepted Accounting Principles (GAAP) allows some flexibility to management to enjoy in some accounting treatment where different alternative judgment can be made for same case.

3 Known as "bottom line" which is single most important items in financial statements indicating the value added activities carried out in the process of business activities over a particular period. 
Pranesh Debnath "Assaying the Impact of Firm's Growth and Performance on Earnings Management: An Empirical Observation of Indian Economy"

describes earnings management as the purposeful intervention in the external financial reporting with a motive of private gains. Earnings management can be pursued in two separate way i.e. firstly, through real activity manipulation wherein management used to adjust the actual activities of an organization to deceive the stake holders and secondly, use of accounting accruals ${ }^{4}$. In the contemporary business setup, accruals are most important component which form a major part of total income. Accruals are decomposed into normal accrual which depends on nature of business like credit policy and credit terms allows to customers etc. On the other hand, abnormal accruals ${ }^{5}$ represent the management choice over which they influence their discretionary powers while reporting the income figure. By this discretionary power they want to report the income in such a way so as to ensure their private gains and deceive the stake holders. In a nutshell, discretionary accruals are adjustment to cash flow based on subjective choice exercise by the management while reporting the income (Rao \& Dandale, 2008) and serve as a proxy for measuring nature and extent of earnings management of a firm in terms of percentage of their total reported assets (Healy \& Wahlen, 1999). As per projection of World Bank, India is one of the fastest growing economy ${ }^{6}$ in the world. To keep this growth up rising, it requires huge inflow of funds from outside. Continued flow of foreign capital (portfolio capital) into the Indian stock market can be fulfilled only when investors are sheltered ${ }^{7}$ from accounting scandals, financial transgression and deceptive earnings management practices (Ajit, Malik, \& Verma, 2013). In this position, one dominant issue that remain on the front burner is how to build up and maintained investors' confidence in the domestic economy through transparent financial reporting (Fodio, Ibikunle, \& Oba, 2013). Study on earnings management is one such instrument which will enable the regulatory bodies in the country to ensure that reported accounting figures are representative ${ }^{8}$ of true and fair picture of financial affairs of firm in particular and economy in general (Roy \& Debnath, 2015a). The practice of earnings management within the firm may leave challenge before the investors (Ajay \& Madhumathi, 2015). Therefore, the present study first explores earnings management practices in corporate enterprises in India by examining the magnitude of discretionary accruals. Discretionary accruals has been calculated through Modified Jones ${ }^{9}$ Model proposed by (Dechow, Sloan, \& Sweeney, 1995). In the second face, study focuses on assessing the impact of firm's growth opportunity and performance on the earnings management considering a period 09 years from 2007 to 2015 for a sample of 84 nonfinancial companies listed on Bombay Stock Exchange. In order to quantify firm growth opportunity and performance, certain proxy parameters have been considered, namely, growth of firm measured by changes in total assets over the previous year, performance has been measured by return on net worth, risk factor measured by Cash Flow Coverage (thereafter CFC) ratio, age of the firm were calculated from the year of incorporation to the year of study and size is measured as natural log value of total assets of current year.

The paper proceeds as follows: review of existing literature were discussed in the Section 2. Variables measurement and the research methodology along with sample selection criteria are presented in the section 3. Section 4 provides the empirical results and interpretation of various statistical techniques utilized for data analyses. Section 5 contains the conclusions and limitations of the study.

\section{REVIEW OF LITERATURE}

In the earnings management literature there are mixed signals on the relationship between firm performance and earnings management. Following are some protuberant studies reviewed in this regard.

4 Which does not generate any immediate cash flow to the organization. The accruals are derived from non-cash transaction or internal adjustment.

5 Unlike normal accruals, abnormal accruals are not closely related to the economic circumstances of business firms.

6 Forecast of World Bank reported in India Today.in New Delhi, Thursday, January 7, 2016.

7 It will provide an additional tool for ensuring that financial figures in a published matches the real economic value of the firm.

8 Since earnings management deteriorate the relevance \& reliability of accounting information (Kaushal, 2013).

9 Jones proposed a model for detecting earnings management in the year 1991 which did not consider the effect of changes in receivables. Later on, this model was modified by Dechow, Sloan, \& Sweeney in 1995 considering such lacuna of Jones model thereby named as Modified Jones Model. Please See (Jones, 1991) and (Dechow, Sloan, \& Sweeney, 1995). 
Pranesh Debnath "Assaying the Impact of Firm's Growth and Performance on Earnings Management: An Empirical Observation of Indian Economy"

(Mahdi, Madhi, \& Masomeh, 2012) and (Rahmani \& Akbari, 2013) examined the effective variables on earnings management. By using the multiple correlation analysis the study documented that there exist negative association between performance coefficient and earnings management while positive relation between firm's size with earnings management. Whereas (Ali, Noor, Khurshid, \& Mahmood, 2015) observed negative relation but (Bassiouny, Soliman, \& Ragab, 2016) observed no significant association. Firm growth opportunity and size are of great importance for its management, depending on the way it uses accounting discretion. (Gorganlidavaji \& Vakilifard, 2014) concluded that firm's growth opportunity is negatively associated with earnings management whereas, size of the firm is positively associated. (Hosseinian \& Ramzani, 2016) attempted to study the rapport between earnings management and profit earnings capacity of firm in Tehran Stock Exchange. The results advocated that there is a significant negative correlation between the variables of shareholders' equity output rate (a proxy of profitability) with earnings management. The study also found significant positive connection between the firm development and earnings management. However, result did not observed any noteworthy relation between the dividend rate, firm size and the share output with smoothing the firms' profit. (Sadeghi \& Zareie, 2015) also observed substantial association between firm performance and earnings management.

A recent study of SEBI DRG ${ }^{10}$ authored by (Ajit, Malik, \& Verma, 2013) found that the average earnings management in Indian non-financial corporate sector in India is 2.9 per cent of the total assets of these firms which is comparable to the estimates in US, Europe and elsewhere in the world. The study also claimed that small firms are more indulge to earnings management than the medium and large size firms. (Kaushal, 2013) concluded the definite existence of earnings management in Indian economy followed by sector wise study of (Kaur, Sharma, \& Khanna, 2014) evaluating the data of 332 companies comprises of six sector during the year 2012-12 and observed that all the sector under study were engage in earnings management. (Goel, 2012) attempted to analyses the earnings management practices in corporate enterprises in India by examining the extent of discretionary accruals as proxy of earnings management. The study explored earnings management issues with respect to service industry and non-service category considering a sample of Bombay Stock Exchange listed profit-making companies for the year 2007 over the period from 2002-03 to 2007-08. An examination of the units found a definite presence of accrual management in the sample companies. Most of the service units have been found to be exercising income-increasing discretionary accruals supported by subsequent findings of (Roy \& Debnath, 2015b). (Akram, Hunjra, Butt, \& Ijaz, 2015) carried out a comparative study of firm performance with earnings management between Indian BSE listed firms and Pakistani KSE listed firms. They concluded that performance and earnings management had a negative association in Pakistani firms. Whereas, in India there were no such significant relation noticed during study period. Another Indian study of (Gill, Biger, Mand, \& Mathur, 2013) on listed manufacturing firms of BSE, observed that the more intense the practice of earnings management greater the adverse effects on corporate return on assets in the following year and also market lowers the share price in long run due to earnings management. (Ali, Noor, Khurshid, \& Mahmood, 2015) scrutinized the encouragement of firm size on earnings management for the textile sector in Pakistan during 2004 to 2013 with a fifty selected firms. The study found that the firm size exercise the significant positive influence over the earnings management. Which also support the findings of another study of US based firms for a long period of 1963 to 2003 carried out by (Copper, Gulen, \& Schill, 2008). (Uwuigbe, Uwuigbe, \& Bernard, 2015) advocated that firm size and corporate strategy exercise positive and significant influence over the earnings management while financial leverage use no significant effect. (Llukani, 2013) analyzed the impact of firm size on earnings management practices of Albanian Market. The study fails to establish any significant impact of size on discretionary accruals. It is generally argued that the level of the investment opportunity set affects net income and net worth and thereby political costs and political risk. This relationship provides management with risk as well as incentive to reduce political costs and political risk associated with a high investment opportunity set by using income decreasing accruals. (Ainajjar \& Belkaoui, 2001) concluded that firm's level of investment opportunity set and managers' accounting choices in multinational firms are positively associated with accounting choices to reduce reported earnings. After reviewing the literature the following hypothesis were formulated.

${ }^{10}$ An empirical study of Development and Research Group (DRG) of Securities and Exchange Board of India (SEBI). 
Pranesh Debnath "Assaying the Impact of Firm's Growth and Performance on Earnings Management: An Empirical Observation of Indian Economy"

$\boldsymbol{H}_{0}{ }^{1}$ : There is significant relation between firm's size and age with earnings management.

$\boldsymbol{H}_{0}{ }^{2}$ : There is significant relation between firm's growth and profitability with earnings management.

Objectives of the study

1. To assess the magnitude of earnings management in selected enterprise in India.

2. To assess the impact of form's growth opportunity and performance on earnings management in selected enterprise in India.

\section{DATA AND METHODOLOGY}

\section{Date Collection \& Description}

Considering the nature of the study data have been collected from the secondary sources of Capitalineplus Corporate Database. Population of the present study consists of all non-financial companies listed in BSE (Bombay Stock Exchange) during 2007 to 2015. Banking, Insurance, and other financial service rendering companies are excluded from the scope of the study due to distinct nature of governance and reporting practices followed in such companies. The final sample of the study consists of 84 (eighty four) companies which covered major share of the industry. Eight different industry were selected for analysis after considering the following criteria- relevant data of the companies are available in Capitalineplus Corporate Database during said period, companies must have market capitalization during this period, accounting year for all the companies ended with end of financial year (i.e. $31^{\text {st }}$ March). Several of the selected company industry groups were too small to form sufficiently large industry matched sample to calculate earnings management variable for sample companies. It was therefore necessary to exclude those industries that had insufficient company observation to ensure unbiased estimation. Following the prior research (DeFond \& Jiambalvo, 1991); (Subramanyam, 1996) industry group with less than six observations were dropped from the sample. Above mentioned criteria resulted in a final sample of 84 companies. Summary of sample and population are reported in the following table.

Table1. Industry wise distribution of Population and Sample.

\begin{tabular}{|l|l|l|l|l|l|}
\hline $\begin{array}{l}\text { SI } \\
\text { No. }\end{array}$ & Industry & $\begin{array}{l}\text { Available } \\
\text { Companies }\end{array}$ & $\begin{array}{l}\text { Selected } \\
\text { Companies }\end{array}$ & $\begin{array}{l}\text { Sample } \\
\text { Representation }(\%)\end{array}$ & $\begin{array}{l}\text { Industry } \\
\text { Representation }(\%)\end{array}$ \\
\hline 1 & Cement Major & 25 & 9 & 36.00 & 10.71 \\
\hline 2 & Cement Mini & 33 & 7 & 21.21 & 8.33 \\
\hline 3 & Hotel & 45 & 8 & 17.78 & 9.52 \\
\hline 4 & Pharmaceuticals & 29 & 18 & 62.07 & 21.44 \\
\hline 5 & Refinery & 23 & 8 & 34.78 & 9.52 \\
\hline 6 & Steel & 22 & 14 & 63.64 & 16.67 \\
\hline 7 & Sugar Integrated & 29 & 11 & 37.93 & 13.10 \\
\hline 8 & Telecommunication & 81 & 9 & 11.11 & 10.71 \\
\hline TOTAL & $\mathbf{2 8 7}$ & $\mathbf{8 4}$ & $\mathbf{2 9 . 2 7}$ & $\mathbf{1 0 0 . 0 0}$ \\
\hline
\end{tabular}

Source: Author's work

The Table 1 reported that the sample drawn from each industries under study are representing from 63 percent to 11 percent in the respective industry. Total selected sample of 84 firm represents 29.27 percent against population of 287 companies. However, sample of industry representation ranges from 8.33 percent to 21.44 percent. Pharmaceuticals and Steel industries are the most represented industries in the sample.

\section{METHODOLOGY}

In the present literature, earnings management is generally quantified through accruals as a proxy parameter. Accruals are measured through two different approaches. One is the balance sheet approach, and the other is the cash flow approach. Following the prevailing literature about accruals calculation it was observed that both approaches have been used by the researchers. However, most of the current research works done by (Goel, 2012); (Agrawal \& Chatterjee, 2015); (Iqbal, Zhang, \& Jebran, 2015); (Ajay \& Madhumathi, 2015) and many others favored the cash flow approach over the balance sheet approach for calculating total accruals. Therefore, in this study I used cash flow approach. 
Pranesh Debnath "Assaying the Impact of Firm's Growth and Performance on Earnings Management: An Empirical Observation of Indian Economy"

\section{Cash Flow Approach of Accruals}

Under this approach it is assumed that total accruals (TA) are the excess of net income (NI) in the year $t$ over the cash flow generated from operating activities in the year t. Hence, TA is calculated through following mathematical formula-

$$
T A_{t}=N I_{t}-C F O_{t}
$$

Where, $T A_{t}=$ total accruals in the year $t ; N I_{t}=$ net income in the year $t ; C F O_{t}=$ cash flow from operating activities in the year $t$.

However, total accruals are not actually proxy of earnings management. Accruals are further decomposed into two categories one is normal accruals ${ }^{11}$ represents companies' normal activity and another one is abnormal accruals which represents the management choice. Therefore, mathematically TA is

$$
T A_{t}=N D A_{t}+D A_{t}
$$

Where, $T A_{t}=$ total accruals in the year $t ; N D A_{t}=$ non-discretionary accruals in the year $t ; D A_{t .}=$ discretionary accruals in the year $t$.

Therefore, discretionary accruals $\left(\mathrm{DA}_{\mathrm{t}}\right)$ can be obtained by deducting non-discretionary accruals $\left(\mathrm{NDA}_{\mathrm{t}}\right)$ from total accruals $\left(\mathrm{TA}_{\mathrm{t}}\right)$.

\section{Estimation of Discretionary Accruals (DA) Using Modified Jones Model}

Since from inception of research on earnings management several model have been proposed for estimation of discretionary accruals as a proxy of earnings management starting from Healy (1985), DeAngelo (1986), Jones (1991) and Modified Jones model proposed by (Dechow, Sloan, \& Sweeney, 1995). However, most of the existing literature argued that Modified Jones Model (1995) provides efficient estimation of earnings management. Therefore, Modified Jones model has been extensively used in the literature to estimate DA (Islam, Ali, \& Ahmad, 2011); (Chen, Chen, \& Huang, 2010); (Alves, 2012); (Kaur, Sharma, \& Khanna, 2014); (Rassas \& Kamardin, 2015); (Toto , Ari, \& Yashinta, 2014); Mahdi, Mahdi \& Mohammad, 2015). Following the preceding literature, present study used the modified Jones model to estimate discretionary accruals. Separate industry-wise regressions have been run for estimating the parameters of the following model.

$$
T A_{i t} / A_{i t-1}=\alpha 1\left(1 / A_{i t-1}\right)+\alpha 2\left(\Delta R E V_{i t}-\Delta R E C_{i t}\right) / A_{i t-1}+a 3\left(P P E i t / A_{i t-1}\right) \ldots \ldots \ldots(i)
$$

Here, a1, a2 and $\mathrm{a} 3$ are firm-specific parameters.

$\mathrm{TA}_{\mathrm{it}}=$ total accruals of firm $\mathrm{i}$ in year $\mathrm{t}$, estimated as excess of net income of firm $\mathrm{i}$ in year $\mathrm{t}\left(\mathrm{NI}_{\mathrm{it}}\right)$ over cash flow from operations in year $\mathrm{t}\left(\mathrm{CFO}_{\mathrm{t}}\right)$.

$\mathrm{A}_{\mathrm{it}-1}=$ total assets of firm $\mathrm{i}$ in year $\mathrm{t}-1$.

$\triangle \mathrm{REV}_{\mathrm{it}}=$ change in revenues of firm $\mathrm{i}$ in the year $\mathrm{t}-1$ to year $\mathrm{t}$.

$\triangle \mathrm{REC}_{\mathrm{it}}=$ change in receivables of firm $\mathrm{i}$ in the year $\mathrm{t}-1$ to year $\mathrm{t}$.

$\mathrm{PPE}_{\mathrm{it}}=$ property, plant and equipment of firm $\mathrm{i}$ in the year $\mathrm{t}$.

$\mathrm{i}$ and $\mathrm{t}=$ subscripts for entity and time period respectively.

The coefficients (i.e., $a 1, a 2$ and $a 3$ ) were estimated through Ordinary Least Square (OLS) method. The estimated values of total accruals, which represent non-discretionary accruals $\left(\mathrm{NDA}_{i t}\right)$, are obtained by putting the estimated parameters, $\alpha_{1}, \alpha_{2}$ and $\alpha_{3}$, in the equation (1). Discretionary accruals $\left(\mathrm{DA}_{i t}\right)$ are then derivative after putting the values in equation (ii).

$$
D A_{i t} / A_{i t-1}=T A_{i t} / A_{i t-1}-N D A_{i t} / A_{i t-1}
$$

\section{Estimation of Regression Model}

The study used multiple regression based on 84 (eighty four) firms considering 09 (nine) years data for each firms. Therefore, after considering firm-year data i.e. panel data which is a combination of time series and cross-section data particulars finally provides 756 (seven hundred fifty six) observations for the study.

\footnotetext{
${ }^{11}$ Normal Accruals are function of revenues and property plant \& equipment (PPE), because revenue growth generally increases accounts receivable or inventory. Similarly, investment in PPE increase the depreciation (non-cash expenditure).
} 
Pranesh Debnath “Assaying the Impact of Firm's Growth and Performance on Earnings Management: An Empirical Observation of Indian Economy"

Independent variables considered for this study are Growth and Performance. Earnings management decision of the firm may be influence by several other factors other than independent variables considered. Therefore, three control variables have been included in this study, namely, firm's Size, Age and Risk factor. The definition and calculation of said variables are presented in the table 2:

Table2. Details descriptions of dependent and independent variables.

\begin{tabular}{|c|c|c|c|}
\hline \multicolumn{2}{|c|}{$\begin{array}{ll}\text { Description } & \& \\
\text { Variables } & \end{array}$} & $\begin{array}{l}\text { Definition for the } \\
\text { proposed variables }\end{array}$ & \multirow{2}{*}{\begin{tabular}{|l} 
Existing Literature \\
(Ajit, Malik, \& Verma, 2013); (Kaur, Sharma, \& Khanna, \\
2014); (Agrawal \& Chatterjee, 2015); (Iqbal, Zhang, \& Jebran, \\
2015); (Ajay \& Madhumathi, 2015)
\end{tabular}} \\
\hline 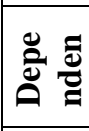 & DA & $\begin{array}{l}\text { Calculated using } \\
\begin{array}{l}\text { Modified Jones (1995) } \\
\text { model }^{12}\end{array} \\
\end{array}$ & \\
\hline \multirow{2}{*}{ 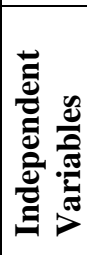 } & Growth $^{13}$ & G row th $=\frac{A_{t}-A_{t-1}}{A_{t-1}}$ & $\begin{array}{l}\text { (Sun \& Rath, 2009); (Agrawal \& Chatterjee, 2015); (Iqbal, } \\
\text { Zhang, \& Jebran, 2015); (Asgari, Pour, Zadeh, \& Pahlavan, } \\
\text { 2015). }\end{array}$ \\
\hline & Performance ${ }^{14}$ & $R O N W=\frac{N I}{S E}$ & $\begin{array}{l}\text { (Gill et al., 2013);(Mahdi et al., 2012); (Sun \& Rath, 2009); } \\
\text { (Ajde \& Aderemi, 2014); (Agrawal \& Chatterjee, 2015); (Iqbal, } \\
\text { Zhang, \& Jebran, 2015) }\end{array}$ \\
\hline \multirow{3}{*}{ 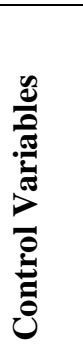 } & Size & Size $=\log (A)$ & $\begin{array}{l}\text { (Llukani, 2013); (Christiawan \& Rahmiati, 2014); (Gill et al., } \\
\text { 2013); (Mahdi et al., 2012); (Sun \& Rath, 2009); (Bassiouny et } \\
\text { al., 2016); (Uwuigbe et al., 2015); (Rahmani \& Akbari, 2013); } \\
\text { (Ali et al., 2015); (Ajit et al., 2013); (Iqbal, Zhang, \& Jebran, } \\
\text { 2015); (Agrawal \& Chatterjee, 2015); }\end{array}$ \\
\hline & Age & Age $=$ YoI - YoS & (Alsaeed, 2006); (Akhtaruddin, 2005); (Bassiouny et al., 2016). \\
\hline & Risk $^{15}$ & $C F C=\frac{C F O+C C E}{I E}$ & (Agrawal \& Chatterjee, 2015). \\
\hline
\end{tabular}

DA = Discretionary Accruals $;$ Size = Firm Size $; \mathrm{A}=$ Total Assets $; \mathrm{RONW}=$ Return on Net Worth $; \mathrm{NE}=$ Net Income; $\mathrm{SE}=$ Shareholders Equity; $\mathrm{CFC}=$ Cash Flow Coverage Ratio; $\mathrm{CCE}=$ Cash and Cash Equivalent; $\mathrm{IE}$ = Interest Expenses; YoI = Year of Incorporation; YoS = Year of Study; Log $(\mathrm{A})=$ Natural log of total assets.

Source: Author's literature survey.

Since the present study is based on panel data which shares both the characteristics of time series and cross section data I used the following multiple regression model considering the above mentioned dependent and independent variables:

Multiple regression model:

$$
D A_{i t}=\beta_{0}+\beta_{1} \text { Profit }_{i t}+\beta_{2} \text { Grow }_{i t}+\beta_{3} \text { Size }_{i t}+\beta_{4} \text { Age } e_{i t}+\beta_{5} \text { Risk }_{i t}+\varepsilon_{i t}
$$

Where,

$D A_{i t}=$ Discretionary Accruals of firm $i$ in the year $t ;$ Grow $_{i t}=$ Growth of firm $i$ in the year $t ;$ Size $_{i t}=$ Size of firm $i$ in the year $t$; Profit ${ }_{i t}=$ Profitability of firm $i$ in the year $t$; Age $_{i t}=$ Age of firm $i$ in the year $t$; Risk $k_{i t}=$ Risk factor of firm $i$ in the year $t ; \beta_{0}=$ intercept of the equation; $\beta_{1}$ to $\beta_{5}=$ coefficients; $\varepsilon_{i t}=$ error term; $i$ and $t=$ subscripts for entity and time period respectively.

\section{Diagnostic test and Model Selection:}

The study applied (Hausman, 1978) test for selection of fixed-effect or random effect regression model. Thereafter, the panel data in this study has been analyzed by using the Satat Software.

\section{EMPIRICAL RESULTS}

This section provides the results and interpretation of various statistical techniques utilized for data analyses.

\footnotetext{
${ }^{12}$ Considering the equation (i) and equation (ii) mentioned above.

${ }^{13}$ Growth is measured by taking a changes in total assets over the last year.

${ }^{14}$ Performance has been measured through RONW (Return on Net Worth) ratio.

${ }^{15}$ Risk has been measured through CFC (Cash Flow Coverage) ratio.
} 
Pranesh Debnath "Assaying the Impact of Firm's Growth and Performance on Earnings Management: An Empirical Observation of Indian Economy"

\section{Descriptive Statistics}

The descriptive statistics for the variables are presented in Table 3. Table 3 shows that the mean DA are positive implying that, on an average, nonfinancial firms are engage in income-increasing earnings management. However, earnings management widely varies across the firms as evident from minimum value and maximum value of DA. The growth of the sample firms indicates a wide range of difference between the minimum value $(-73.17)$ and the maximum value $(369.29)$ followed by very high standard deviation (32.139). This means that the growth varies widely across the sample firms. Almost an identical picture is evident for firms' profitability. Here also, a wide range of difference exists between the maximum value (85.27) and the minimum value $(-258.95)$ of profit with a higher value of standard deviation (20.617). This simply implies that performance varies widely across the sample firms. Further the mean value of Profit of the sample firms is positive (11.739) which means that sample firms are, on an average, profit making to the degree of 11.739 per cent. Wide difference across sample firms is evident in respect of size, age and risk factor of the firms as well.

Table3. Descriptive Statistics.

\begin{tabular}{|c|c|c|c|c|c|}
\hline ariable | & obs & Mean & Std. Dev. & Min & $\operatorname{Max}$ \\
\hline $\begin{array}{r}\text { DA } \\
\text { Growth } \\
\text { Profit } \\
\text { size } \\
\text { Age } \\
\text { Risk }\end{array}$ & $\begin{array}{l}756 \\
756 \\
756 \\
756 \\
756 \\
756\end{array}$ & $\begin{array}{l}1598879 \\
18.12108 \\
11.73889 \\
7.032084 \\
39.05952 \\
21.47593\end{array}$ & $\begin{array}{l}.3001574 \\
32.13904 \\
20.61743 \\
2.544234 \\
23.68721 \\
206.6746\end{array}$ & $\begin{array}{r}.000289 \\
-73.17 \\
-258.95 \\
-.597837 \\
3 \\
-2740.32\end{array}$ & $\begin{array}{r}7.143778 \\
369.29 \\
85.27 \\
12.66096 \\
113 \\
4014.56\end{array}$ \\
\hline
\end{tabular}

Source: Author's calculation through stata software.

\section{Variance Inflation Factor (VIF) Test}

In the Table 4. Variance Inflation Factor (VIF) test has been done to detect the multicollinearity problem among the explanatory variables. As reported in Table 3 the Variance Inflation Factor (VIF) in relation to all the variables considered are consistently less than 10 and also the Tolerance value statistics are consistently greater than the common threshold of 0.10 for all the variables under consideration. This situation confirmed the absence of multicollinearity among the explanatory variables.

Table4. Variance Inflation Factor (VIF).

\begin{tabular}{r|cc} 
Variable & VIF & Toler ance \\
\hline Growth & 1.08 & 0.927153 \\
Profit & 1.07 & 0.932780 \\
Size & 1.04 & 0.960616 \\
Age & 1.03 & 0.968166 \\
Risk & 1.00 & 0.995700 \\
\hline Mean VIF & 1.05 & \\
\hline
\end{tabular}

Source: Author's calculation through stata software.

\section{Correlation}

Table5. Correlation Matrix.

\begin{tabular}{|c|c|c|c|c|c|c|}
\hline 1 & DA & Growth & Profit & size & Age & Risk \\
\hline $\begin{array}{r}\text { DA } \\
\text { Growth } \\
\text { Profit } \\
\text { Size } \\
\text { Age } \\
\text { Risk }\end{array}$ & $\begin{array}{c}1.0000 \\
0.3867^{*} \\
-0.0327^{*} \\
-0.0530 \\
0.0332 \\
-0.0119\end{array}$ & $\begin{array}{c}1.0000 \\
0.2407^{*} \\
0.0368 \\
-0.1117^{*} \\
0.0099\end{array}$ & $\begin{array}{l}1.0000 \\
0.0824^{*} \\
0.0206 \\
0.0538\end{array}$ & $\begin{array}{l}1.0000 \\
0.1532 \% \\
0.0290\end{array}$ & $\begin{array}{r}1.0000 \\
-0.0222\end{array}$ & 1.0000 \\
\hline
\end{tabular}

Source: Author's calculation through stata software. 
Pranesh Debnath "Assaying the Impact of Firm's Growth and Performance on Earnings Management: An Empirical Observation of Indian Economy"

The Table 5 reports the correlation results showing that firm's growth is positively correlated with discretionary accruals (DA). However, among the control variables size and risk factor are negatively correlated with discretionary accruals except the age which is positively correlated with discretionary accruals.

\section{Regression Results}

Table 6 reports the results of multiple regression analysis based on firm-year observation with Fixed Effect Model (thereafter FEM). In this Model which shares both cross section and time series effect. The F-statistic value of 29.78 with a P-value of 0.00 indicates fitness and statistical significance of the model. The Adjusted R-square is the coefficient of determination, and its value of 0.1601 indicate that all the explanatory variables in the model jointly explain to the extent of 16.01 per cent variation in the discretionary accruals, which means that there are other variables responsible for the rest of the variation in the discretionary accruals. The regression analysis provides a significant positive association between firm's growth and level of discretionary accruals showing that firm's growth increases earnings management. This result contradicts many of the prior literature like (Chen \& Lui, 2010); (Ainajjar \& Belkaoui, 2001); and (Asgari, Pour, Zadeh, \& Pahlavan, 2015) who found an inverse association between firm's growth and earnings management. Similarly, the regression analysis also provides evidence of a significant negative association between firm's performance and discretionary accruals, which shows that well performing firms are engaged in low level of earnings management. This result is in line with (Naveed, Iqbal, Ali, \& Shoaib, 2012); (Hosseinian \& Ramzani, 2016) who observed an adverse association between profitability and discretionary accruals. The regression analysis also shows that firm size and discretionary accruals are negatively related. It means that large firms are less engage in earnings management than that of small firm (Ajit, Malik, \& Verma, 2013); (Roy \& Debnath, 2015b). However, age of the firms are significantly and positively related with the discretionary accruals which indicates that aged firms are more involve in earnings management than the new firm. Which contradicts with the basic theory wherein it is asserted that aged firms are more abide by the rules and regulation than the newly establish firm. Regression analysis further provides an evidence that, risk factor of the firm is negatively associated with discretionary accruals. This results signified that those firms are undertaking huge risk in the business operation they are less involve in earnings management and firm having lower level of risk are more indulge in earnings management.

After applying the Hausman (1978) test Fixed Effect Model (FEM), has been decided for panel data in this study. Table 7 shows the results of the test which indicate that the chi-square statistic value of cross-section random is 40.33 , which is very large and also the p-value (0.078) of cross-section random is insignificant thus indicating that the use FEM is an appropriate choice.

Table6. Regression Analysis

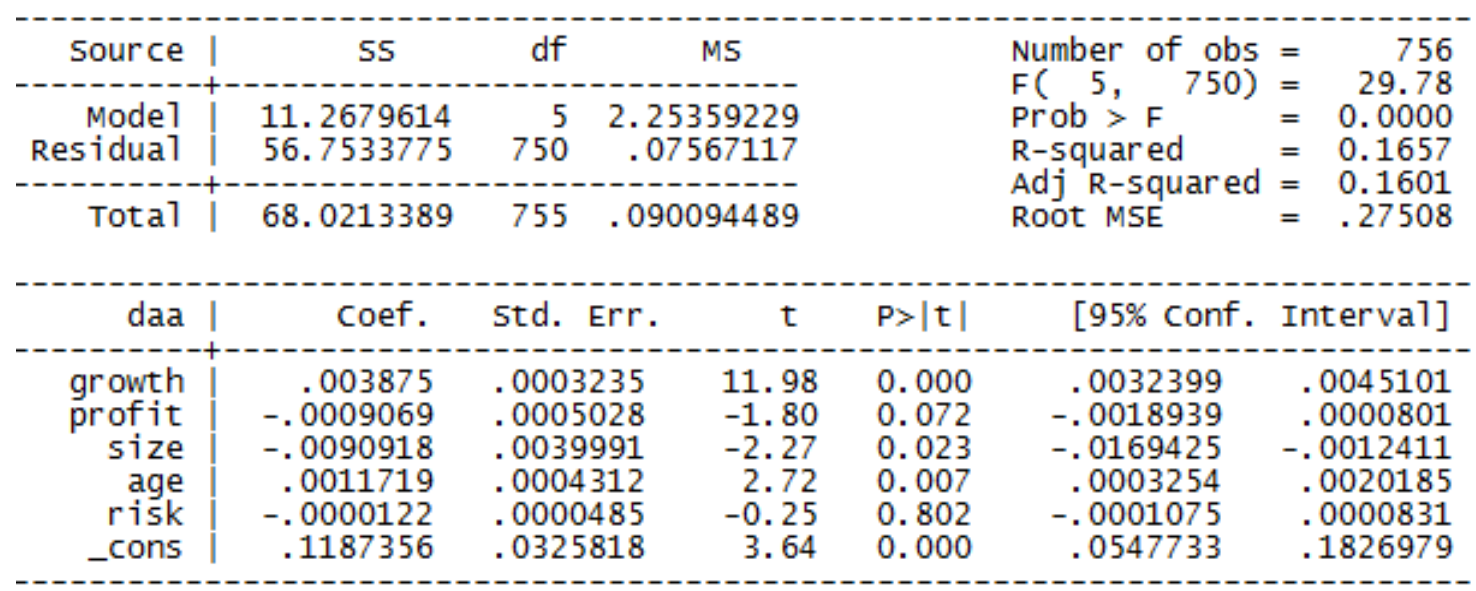

Source: Author's calculation through stata software.

Table7. Hausman Test

$\begin{array}{lll}\text { Test summary } & \text { | chi-sq. Statistic } & \text { P-value } \\ \text { cross-section random | } & 40.33 & 0.078\end{array}$

Source: Author's calculation through stata software. 
Pranesh Debnath "Assaying the Impact of Firm's Growth and Performance on Earnings Management: An Empirical Observation of Indian Economy"

\section{CONCLUSION}

This study focused on investigating the impact of firm's growth and performance along with other control variables on earnings management in Indian non-financial firms for a period of nine years from 2007 to 2015. The multiple panel regression analysis under the fixed effect model has been employed for estimation of impact of explanatory variables over discretionary accruals. The empirical results provide evidence of a significant positive relationship between firm's growth opportunity and discretionary accruals signifying the fact that increasing the growth of a firm leads to an increase in the accounting choice exercised by the management while reporting the earnings figure. It is frequently argued that high growth firms with lower asset value and higher future discretionary investment expenditure by managers are actually hard to observe and monitor, consequently managers are more likely to engage in opportunistic reporting behaviour (Skinner, 1993); (Skinner \& Sloan, 2002). Furthermore, the results provide evidence of a noteworthy negative connotation between performance and discretionary accruals showing that well performing firms are less engaged in earnings management than the loss suffering firms. This findings supports many of the existing literature like (Ajit, Malik, \& Verma, 2013); (Roy, 2016). On the other hand, results advocated a momentous negative association between firm size and earnings management which is fairly in line with the current literature like (Ali, Noor, Khurshid, \& Mahmood, 2015). The study moreover found the optimistic relation between firm's age and earnings management. This findings contradicts with the philosophy of financial reporting as firms functioning for longer period tends to show a better state of affairs than new firms (Alsaeed, 2006) and also they try to enhance their reputation and image in the market (Akhtaruddin, 2005). Another control variables namely, the risk factor have been found insignificantly related with earnings management. Overall, the results show that firm's growth potentiality and performance have important implications on the opportunistic behaviour by managers.

\section{LIMITATIONS OF THE STUDY}

Present study is based on limited firm-year observations and collected from Capitalineplus corporate database. Therefore, originality and authenticity of statistical inference drawn based on such data rest with said sources.

\section{REFERENCES}

[1] Agrawal, K., \& Chatterjee, C. (2015). Earnings Management and Financial Distress: Evidence from India. Global Business Review, 16(5).

[2] Ainajjar, F., \& Belkaoui, A. R. (2001). Growth opportunities and earnings management. Managerial Finance, 27(12), 72-81.

[3] Ajay, R., \& Madhumathi, R. (2015). Institutional Ownership and Earnings Management in India. Indian Journal of Corporate Governance, 8(2), 119-136.

[4] Ajde, F. M., \& Aderemi, A. A. (2014). The Effects of Earnings Management on Dividend policy in Nigeria: An Empirical Note. The SIJ Transactions on Industrial, Financial \& Business Management, 2(3), 145-152.

[5] Ajit, D., Malik, S., \& Verma, V. K. (2013). Earnings Management in India. Securities \& Exchange Board of Iindia DRG Study, 1-27.

[6] Akhtaruddin, M. (2005). Corporate mandatory disclosure practices in Bangladesh. The International Journal of Accounting, 40(4), 399-422.

[7] Akram, M. A., Hunjra, A. I., Butt, S., \& Ijaz, I. (2015). Earnings management and organizational performance: Pakistan VS India. Basic Research Journal of Business Management and Accounts, 4(9), 211-220.

[8] Ali, U., Noor, M. A., Khurshid, M. K., \& Mahmood, A. (2015). Impact of Firm Size on Earnings Management: A Study of Textile Sector of Pakistan. European Journal of Business and Management, 7(28), 47-56.

[9] Alsaeed, K. (2006). The Association Between Firm-Specific Characteristics and Disclosure: The Case of Saudi Arabia. Journal of American Academy of Business, Cambridge, 7(1), 310-321.

[10] Alves, S. (2012). Ownership Structure and Earnings Management: Evidence from Portugal. Australasian Accounting, Business and Finance Journal, 6(1), 57-74. 
Pranesh Debnath "Assaying the Impact of Firm's Growth and Performance on Earnings Management: An Empirical Observation of Indian Economy"

[11] Asgari, R. M., Pour, A. A., Zadeh, A. R., \& Pahlavan, S. (2015). The Relationship Between Firm's Growth Opportunities and Firm Size on Changes Ratio in Retained Earnings of Listed Companies in Tehran Stock Exchange. International Journal of Innovation and Applied Studies, 10(3), 923-931.

[12] Bassiouny, S. W., Soliman, M. M., \& Ragab, A. (2016). The Impact of Firm Characteristics on Earnings Management: An Empirical Study on The Listed Firms in Egypt. The Business and Management Review, 7(2), 91-101.

[13] Beneish, M. D. (2001). Earnings Management: A Prespective. Managerial Finance, 27(12), 317.

[14] Chen, K. Y., \& Lui, J. L. (2010). Earnings Management, CEO Domination, and Growth Opportunities: Evidence From Taiwan. International Journal of Public Information Systems, 1, 43-69.

[15] Chen, Y., Chen, C., \& Huang, S. (2010). An Appraisal of Financially Distressed Companies' Earnings Management: Evidence From Listed Companies in China. Pacific Accounting Review, 22(1), 22-41.

[16] Copper, M., Gulen, H., \& Schill, M. (2008). Assets Growth and Cross Section of Stock Returns. Journal of Finance, 63(4), 1069-1651.

[17] Dechow, P. M., Sloan, R. G., \& Sweeney, A. P. (1995). Detecting Earnings Management. The Accounting Review, 70(2), 193-225.

[18] DeFond, M. L., \& Jiambalvo, J. (1991). Incidence and Circumstances of Accounting Error. The Accounting Review, 66(3), 643-655.

[19] Fama, E., \& Jensen, M. (1983). Agency Problems and Residual Claims. Journal of Law and Economics, 26(2), 327-349.

[20] Fodio, M. I., Ibikunle, J., \& Oba, V. C. (2013). Corporate Governance Mechanisms and Reported Earnings Quality in Listed Nigerian Insurance Firms. International Journal of Finance and Accounting, 2(5), 279-286.

[21] Gill, A., Biger, N., Mand, H. S., \& Mathur, N. (2013). Earnings Management, Firm Performance, and The Value of Indian Manufacturing Firms. International Research Journal of Finance and Economics(116), 13-26.

[22] Goel, S. (2012). Demystifying Earnings Management Through Accruals Management: An Indian Corporate Study. Vikalpa, 37(1), 49-56.

[23] Gorganlidavaji, J., \& Vakilifard, H. (2014). The Effect of Firm Size and Growth Opportunity on Accounting Discretion and its Relationship with Future Stock Return (Management Opportunism Test). European Online Journal of Natural and Social Sciences, 3(3), 511-521.

[24] Hausman, J. (1978). Specification tests in econometrics. Econometrica, 46(6), 1251-1271.

[25] Healy, P. M., \& Wahlen, J. M. (1999). A review of the earnings management literature and its implications for standard setting. Accounting Horizons, 13, 365-383.

[26] Hosseinian, M., \& Ramzani, J. (2016). Investigate the Relationship Between Earnings Management and Profitability the Firms Listed in the Tehran Stock Exchange. Journal of productivity and development, 2(4), 86-95.

[27] Iqbal, A., \& Strong, N. (2010). The Effect of Corporate Governance on Earnings Management Around UK Rights Issues. International Journal of Managerial Finance, 6(3), 168-189.

[28] Iqbal, A., Zhang, Z., \& Jebran, K. (2015). Corporate Governance and Earnings Management: A Case of Karachi Stock Exchange Listed Companies. Indian Journal of Corporate Governance, 8(2), 103-118.

[29] Islam, A., Ali, R., \& Ahmad, Z. (2011). Is Modified Jones Model Effective in Detecting Earnings Management? Evidence from A Developing Economy. International Journal of Economics and Finance, 3(2), 116-125.

[30] Jensen, M., \& Meckling, W. (1976). Theory of The Firm: Managerial Behavior, Agency Costs and Ownership Structure. Journal of Financial Economics, 3, 350-360.

[31] Jones, J. J. (1991). Earnings Management During Import Relief Investigations. Journal of Accounting Research, 29, 193-228. 
Pranesh Debnath "Assaying the Impact of Firm's Growth and Performance on Earnings Management: An Empirical Observation of Indian Economy"

[32] Kaur, R., Sharma, K., \& Khanna, A. (2014). Detecting Earnings Management in India: A sectorwise study. European Journal of Business and Management, 6(11), 11-18.

[33] Kaushal, M. (2013). An Analysis of Earnings Management in India: An Empirical Study. Indian Journal of Finance, 7(6), 45-55.

[34] Llukani, T. (2013). Earnings Management and Firm Size: An Empirical Analysis in Albanian Market. European Scientific Journal, 9(16), 135-143.

[35] Mahdi, M., Madhi, S., \& Masomeh, N. (2012). A Study of Effective Variables on Earnings Management: Iranian Evidence. Research Journal of Applied Science, Engineering and Technology, 4(17), 3088-3094.

[36] Naveed, A., Iqbal, S. M., Ali, M. Q., \& Shoaib, H. (2012). Earnings Management and Firms' Profitability Evidence from Pakistan. European Journal of Economics, Finance \& Administrative Sciences, 47, 13.

[37] Rahmani, S., \& Akbari, M. A. (2013). Impact of Firm Size and Capital Structure on Earnings Management: Evidence from Iran. World of Sciences Journal, 1(17), 59-71.

[38] Rao, N., \& Dandale, S. (2008). Earnings Management: A Study of Equity Rights Issues in India. The ICFAI Journal of Applied Finance, 14(1), 20-34.

[39] Rassas, A. A., \& Kamardin, H. (2015). Director Independence, Ownership Concentration and Earnings Quality in Malaysia. Australian Journal of Basic and Applied Sciences, 9(9), 70-77.

[40] Roy, C. (2016). Financial Reporting Irregularaties in Indian Public Sector Units: An Analysis of Current Practices. South Asian Journal of Management, 23(1), 139-163.

[41] Roy, C., \& Debnath, P. (2015a). Earnings Management Practices in Financial Reporting of Public Enterprises in India: An Empirical Test with M-Score. Hind Business Review, 1(1), 7-14.

[42] Roy, C., \& Debnath, P. (2015b). Opportunistic Use of Accrual Earnings in Financial Reporting: A Study of BSE Listed Firms in India. International Journal of Computational Engineering \& Management, 18(4), 9-15.

[43] Sadeghi, S. A., \& Zareie, B. (2015). Relationship Between Earnings Management and Financial Ratios at The Family Firms Listed in The Tehran Stock Echange. Indian Journal of Fundamental and Applied Life Sciences, 5(3), 1411-1420.

[44] Schipper, K. (1989). Commentary: Earnings Management. Accounting Horizons, 3(4), 91-102.

[45] Skinner, D. J. (1993). The Investment Opportunity Set and Accounting Procedure Choice: Preliminary Evidence. Journal of Accounting and Economics, 16(4), 407-445.

[46] Skinner, D. J., \& Sloan, R. G. (2002). Earnings Surprises, Growth Expectations and Stock Returns or don't let an Earnings Torpedo sink Your Portfolio. Review of Accounting Studies, 7, 289-312.

[47] Subramanyam, K. R. (1996). The Pricing of Discretionary Accruals. Journal of Accounting and Economics, 22(3), 249-281.

[48] Toto , R., Ari, D., \& Yashinta, S. (2014). The Effect of Earnings Management to Issuance of Audit Qualification: Evidence from Indonesia. Journal of Business Studies Quarterly, 6(1), 128.

[49] Uwuigbe, U., Uwuigbe, O. R., \& Bernard, O. (2015). Assessment of The Effects of Firms' Characteristics on Earnings Management of Listed Firms in Nigeria. Asian Economic and Financial Review, 5(2), 218-228.

\section{AUTHORS' BIOGRAPHY}

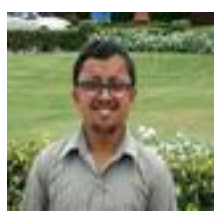

Shri Pranesh Debnath, is currently working as an Assistant Registrar (Finance) at Tripura University. Apart from the above he is also working as Guest Faculty in Department of Business Management of same University as an additional charge. Shri Debnath did his B. Com (in 2011) and M.Com (in 2013) from Tripura University as Year Topper in both degrees. He is recipient of Brilliant Performance Award in National Accounting Talent Search Examination in 2014 Conducted by Indian Accounting Association. Shri Debnath qualified four times UGC-NET, once in UGC-JRF and once in NorthEaster SET. He has published may research articles and presentation to his credit. His current interested areas of research are Earnings Management, Corporate Governance and Corporate Financial Reporting. 